\title{
O DEMOKRACJI I SPRAWACH SPOŁECZNYCH NA PRZYKLADZIE WYBRANYCH PRZEDSTAWICIELI PERSONALIZMU XX WIEKU
}

\begin{abstract}
Wstęp
Używając pojęcia „demokracja” trudno pominąć starożytne Ateny. To właśnie tam narodził się system polityczny, do którego dzisiaj odwołują się politycy państw, zwłaszcza europejskich. Wówczas był to eksperyment, który zakładał, iż będą to rządy totalne tzn. sprawowane przez ludzi do tego wybranych. Władzę mogli sprawować ci, którzy spełniali dwa warunki: mężczyźni posiadający obywatelstwo Aten. Wyłączeni byli niewolnicy, kobiety oraz dzieci ${ }^{1}$. Dzisiaj demokracja stała się przedmiotem walki politycznej między różnymi obozami, nie bacząc na źródłosłów, historię powstania, czy podłoże filozoficzne. Różnic w rozumieniu demokracji w kontekście przeszłości i teraźniejszości jest wiele. Już sam powyższy przykład pokazuje, że demokracja starożytna nie była nacechowana egalitarnym podejściem do kwestii społecznych. Dominowała przecież demokracja bezpośrednia. Dzisiaj natomiast jednym tchem wśród wartości, które przyświecają demokracji wymienia się m.in. wspomnianą równość czy wolność ${ }^{2}$. Oczywiście wartości te przyświecały demokracji ateńskiej, jednakże nie były tak rozumiane jak dzisiaj. Warto także przypomnieć zastrzeżenie Arystotelesa, który właśnie w równości widział zagrożenie dla systemu demokratycznego. Zastanawiał się, jak można wcielić taką wartość w życie, skoro obywatele dzielą się na biednych i bogatych, na tych co rządzą i tych, którzy podlegają rządzeniu ${ }^{3}$. Stąd w jego ocenie demokracja nie była jedynym możliwym do zaakceptowania systemem.

Demokracja to system, który jest oparty na rządzie ludu ${ }^{4}$. W XIX w. prezydent USA Abraham Lincoln rozszerzył tę definicję mówiąc, iż ,demokracja są to rządy ludu, przez lud, dla ludu"5. Nie mniej jednak system, który został stworzony na

1 T. Słupik, Narodziny demokracji w Grecji klasycznej w czasach reform Klejstenesa i Peryklesa, „Studia Politicae Universitatis Silesiensis” 2017, nr 19, s. 36.

2 A. Swift, Wprowadzenie do filozofii politycznej, przeł. A. Krzynówek, Kraków 2010, s. 197-205.

3 M. Malmon, Arystotelesa poszukiwania idealnego ustroju państwowego, „Kultura i Wartości” 2016, nr 2, s. 16.

4 H. Zdebski, Historia myśli politycznej i prawnej, Warszawa 2013, s. 1.

5 A. Swift, Wprowadzenie..., dz. cyt., s. 176.
\end{abstract}


przełomie VII/VI w. p.n.e. a później doprecyzowany przez Arystotelesa i następnych filozofów przeszedł swoistą metamorfozę dzięki kolejnym „rewolucjom”, jakie miały miejsce w filozofii politycznej. Swoje rozumienie demokracji przyniósł zarówno liberalizm jak również komunitaryzm, a także personalizm.

Obchodząc 100-lecie odzyskania przez Polskę niepodległości i umacniania państwa demokratycznego, należy zastanowić się jaką demokrację chcemy tworzyć i z jakich źródeł chcemy korzystać. Personalizm, jako nurt stawiający w centrum osobę rozumianą jako podmiot, nigdy zaś przedmiot działania, wypracował własne podejście w kwestii rozumienia demokracji. Wydaje się słusznym, aby przedstawić tę myśl celem refleksji nad tym, jakie elementy wypracowane na gruncie tej filozofii mogą nam pomóc w realizacji, utrwalania demokracji polskiej, ale także europejskiej.

\section{Osoba jako byt spoleczny}

Chcąc dobrze sformułować myśl dotyczącą demokracji w personalizmie należy przynajmniej zasygnalizować kwestię dotyczącą relacji między osobą a wspólnotą. Wśród najważniejszych cech personalizmu, do których zaliczamy takie elementy jak: podmiotowość, samostanowienie, niezbywalność praw ${ }^{6}$, pojawia się także kwestia społeczna.

Jak zaznacza Cz. Bartnik, „osoby i społeczności nie można oddzielić: jedna jest zrozumiała przez drugą" . Należy w tym miejscu zaznaczyć, iż pogląd ten nie jest in sensu stricto oryginalny. Wspominany już wyżej Arystoteles w swoim dziele Polityka zaznaczył, iż człowiek jest z natury przeznaczony do życia politycznego. Personalizm czerpie jednak z tych źródeł doprecyzowując rolę osoby w stosunku do wspólnoty i odwrotnie. Każda osoba jest nakierowana na życie społeczne. Dzięki temu, że żyje w społeczności i jest na nią otwarta, następuje jej rozwój osobisty i społeczny. Oznacza to, że wspólnota wpływa na holistyczny rozwój osoby, ale także konkretna osoba ma wpływ na rozwój społeczności, wśród której żyje. Personalizm odrzuca myślenie, w którym defetyzm bierze górę nad chęcią rozwoju. Przykładem takiego działania jest brak udziału w demokratycznych wyborach, które uzasadniania się stwierdzeniem, iż głos pojedynczej osoby nie ma wpływu na zmiany w państwie. W personalizmie podkreśla się ważną zasadę, w myśl której „każdy człowiek ma zadane sobie niezamienialne miejsce, własny czas i niepowtarzalne zadanie do wykonania"s. Stąd przedstawiciele tego nurtu postulują, aby skupić się na takich społecznościach, które mają wpływ na kształtowanie charakteru już od samego początku tj. rodzinie, szkole, Kościele i narodzie. Z racji omawianego zagadnienia słusznym będzie, aby skupić się na relacjach dotyczących osoby i narodu.

Nie bez powodu naród znajduje się na końcu tego „łańcucha” opisującego najważniejsze relacje między osobą a wspólnotą. Naród - jak zaznacza Andrzej Zwoliński - jest zwieńczeniem relacji rodzinno-rodowych ${ }^{9}$. Opisując czym jest naród

6 W. Szewczyk. Kim jest człowiek. Zarys antropologii filozoficznej, Tarnów 2009, s. 132.

7 Cz. Bartnik, Personalizm, Lublin 2008, s. 188.

8 Cz. Bartnik, Personalizm..., dz. cyt., s. 190.

9 A. Zwoliński, Wprowadzenie do rozważań o narodzie, Kraków 2005, s. 18. 
należy wskazać, iż można scharakteryzować to pojęcie używając dwóch kategorii: przedmiotowej i podmiotowej. Od strony przedmiotowej naród to zespół ludzi i konkretne terytorium, które zamieszkują. Zaś od strony podmiotowej jest związany z językiem, kulturą, czy świadomością narodową ${ }^{10}$. W ujęciu personalizmu ważniejszą jest kwestia podmiotowości. Naród jest wspólnotą, którą łączy kilka istotnych elementów: wspólna historia, język, kultura. Członkowie narodu są związani więzami moralnymi. To od zachowania konkretnej osoby zależy, czy będzie dawać świadectwo czy antyświadectwo. Czynnikiem wyróżniającym naród w personalizmie jest kultura zarówno materialna, jak również duchowa. Jak zaznaczył Jan Paweł II w adhortacji apostolskiej Ecclesia in Europa każda osoba jest wezwana do budowania „miasta godnego człowieka” (EE 97). Poprzez budowanie należy rozumieć wspólny wkład w codzienne życie lokalnych społeczności (miast, gmin), które mają wpływ na globalny rozwój narodu. Oprócz pewnych cech, w pojęciu narodu mieści się również swoista deontologia. Dla członka narodu pojawiają się powinności względem tej wspólnoty. Etyka personalistyczna mówi o kilku istotnych powinnościach takich jak: podjęcie służby wojskowej w sytuacji zagrożenia, pielęgnowanie w życiu codziennym wartości bliskich wszystkim obywatelom (konkretne wartości zostały już wcześniej wymienione), czy szacunek względem innych narodów z poszanowaniem ich dorobku kulturowego ${ }^{11}$. Personalizm jest o tyle ciekawym pomysłem, o ile jego przedstawiciele proponują rozumienie demokracji przez pryzmat obiektywnych wartości. Neguje wszelkie relatywizmy, które dochodzą do głosu w świecie filozofii polityki. Jednym z takich przykładów jest pogląd Richarda Rortyego, amerykańskiego neopragmatysty. Wyraził on przekonanie, iż w relacji filozofia a demokracja, pierwszeństwo ma demokracja ${ }^{2}$. Skutki takiego stanowiska są jasne. Chodziło o to, aby nie zadawać pytań dotyczących natury człowieka, a więc także kwestii odnoszących się do etyki. Oczywiście, chęć rozdzielenia etyki od polityki nie jest nowa (np. poglądy N. Machiavellego ${ }^{13}$ ), jednakże od nowożytności głosy te są coraz bardziej słyszalne.

\section{Propozycje dotyczące działalności społeczno-politycznej w ujęciu wybranych personalistów}

\section{Przejście od teorii do praktyki - Emmanuel Mounier}

Dla personalizmu francuskiego niewątpliwie Emmanuel Mounier (1905-1950) stał się pionierem w kwestiach społeczno-gospodarczych. Skupił wokół siebie in-

10 S. Kowalczyk, Człowiek a społeczność. Zarys filozofii społecznej, Lublin 2005, s. 275.

11 T. Ślipko, Zarys etyki szczegółowej, t. 2, Kraków 2010, s. 241-243.

12 R. Rorty, Obiektywność, relatywizm, prawda, przeł. J. Margański, Warszawa 1999, s. 261-291.

13 T. Raburski, Niccolò Machiavelli: klasyczny realizm i republikanizm, „Filozofia Publiczna i Edukacja Demokratyczna” 2011, nr 1, s. 114. 
telektualistów, tworząc w 1932 r. ruch Esprit ${ }^{14}$. Zanim jednak doszedł do tego, aby opisywać relacje osoby w systemie społeczno-polityczno-gospodarczym, wyszedł z krytyką utożsamiania osoby wyłącznie z myślą. Hołdował tezie, iż dostęp do człowieka, do konkretnej osoby wynika z jej doświadczenia, a więc z relacji międzyludzkich. Konsekwencja takiego myślenia była jedna. Mounier postulował zmianę paradygmatu myślenia i postawienie osoby w centrum filozofii. Osoba to podmiot - pisał Mounier - który domaga się zachowania jej godności i możliwości wchodzenia w relacje (wspólnotowości), natomiast cechą wspólnoty ma być otwartość na dialog ${ }^{15}$.

Wśród dominujących wątków w filozofii E. Mouniera należy zauważyć kwestię dotyczącą wolności. Fakt ten nie dziwi zwłaszcza dlatego, iż w czasach tego francuskiego personalisty wolność była odmieniana przez wszystkie przypadki, zwłaszcza przez indywidualistów i liberalistów. Można wymienić w tym miejscu m.in. F. Hayeka bądź I. Berlina. Pierwszy z wymienionych w jednym ze swoich esejów próbował na wszelkie sposoby udowodnić, iż dotychczasowa krytyka liberalizmu (zwłaszcza ze strony komunitarystów i personalistów) wynika wyłącznie z błędnego rozumienia indywidualizmu. Na poczet takiego toku rozumowania przedstawił podział indywidualizmu na "prawdziwy” (antyracjonalny) i fałszywy (racjonalny) ${ }^{16}$. Jednym $\mathrm{z}$ argumentów przeciwko krytyce indywidualizmu jest fakt, iż to nie egoizm jest domeną tego nurtu, tylko możliwość decydowania o tym, co w danej sytuacji jest pożyteczne ${ }^{17}$. Wobec tak rozumianej wolności (jako wyboru najbardziej pożytecznego dla jednostki) Mounier przedstawił własną koncepcję. Stwierdził, iż wolność jest kategorią duchową, nie zaś materialną. Nie jest rzeczą; jest natomiast przyjęciem przez osobę i w drugiej osobie. Dzięki temu wolność jest „do przeżycia”, nie zaś do oglądania ${ }^{18}$.

Opisując życie społeczne nawoływał do autentycznego zaangażowania. Wszelkie działanie ma wpływać nie tylko na rozwój społeczności, wśród której się żyje, ale także na rozwój osobisty. Jednakże, aby mogło to nastąpić - w ocenie francuskiego personalisty - należało znaleźć zagrożenia uniemożliwiające podjęcie aktywności społeczno-politycznej. W jego opinii można było wskazać na dwa elementy: rewolucyjny aktywizm i idealistyczny naturalizm ${ }^{19}$. U źródeł zaangażowania nie może być tylko refleksja albo tylko działanie. Aby móc właściwie działać, podejmować decyzje, trzeba być otwartym na dyskusje, tworzyć plany, a następnie działać według

${ }^{14}$ Cz. Bartnik, Personalizm ..., dz. cyt., s. 125.

15 K. Guzowski, M. Kosche, Personalizm jako próba jednoczenia „zwaśnionych” antropologii, „Horyznoty Polityki” 2016, nr 19, s. 63.

16 F. Hayek, Indywidualizm i porządek ekonomiczny, przeł. G. Łuczkiewicz, Kraków 1998, s. $10-11$.

17 F. Hayek, Indywidualizm..., dz. cyt., s. 23.

18 E. Mounier, Co to jest personalizm, przeł. E. Krasnowolska, Warszawa 1964, s. 193.

19 K. Sacharczuk, Mounierowskie rozumienie wolności, zaangażowania i komunikacji dla praksis życia osobowego człowieka, „Bielańskie Studia Teologiczne” 2016, nr 2, s. 107. 
określonego planu. Ciekawym jest także wskazanie na stadia życia opisanego przez duńskiego filozofa S. Kierkegaarda ${ }^{20}$. Zaznacza on, iż jeśli człowiek zatrzymuje się na poziomie estetycznym, gdzie najważniejszymi elementami jest rozrywka, to trudno będzie taką osobę skłonić do działania, które przecież niesie ze sobą „zagrożenia” poświęcenia swoich potrzeb na rzecz wartości wyższych, np. dobra drugiej, całkowicie nieznanej osoby ${ }^{21}$. W tym miejscu Mounier znajduje pole odpowiedzialności personalizmu za człowieka. Zaznacza, iż etap estetyczny jest związany z obojętnością ${ }^{22}$. Należy ją przezwyciężać w człowieku. Wtedy będzie on zdolny do pojęcia wyboru, do wzięcia odpowiedzialności za siebie i za drugiego człowieka ${ }^{23}$.

W kontekście życia społecznego należy jeszcze uwzględnić kwestię dotyczącą demokracji. $Z$ jednej strony Mounier zauważa, że jest ona system „dobrym” dla wybranej grupy społecznej, zazwyczaj tej bogatej, lepiej sytuowanej ${ }^{24} . Z$ drugiej zaś strony zgadza się z tym, iż takie wartości jak: równość czy wolność, które leżą u podstaw demokracji parlamentarnej, są potrzebne w życiu społecznym ${ }^{25}$. Czyni jednak zastrzeżenie, że jeśli wartości te służą wyłącznie konkretnej grupie interesów i czynią resztę ,poddanymi”, to na pewno nie można mówić wtedy o rządach ludu.

\section{Od demokracji liberalnej do demokracji personalistycznej - Jacques Maritain}

W refleksji na temat demokracji w personalizmie trudno byłoby pominąć francuskiego filozofa, teologa J. Maritaina (1882-1973). Przeszedł burzliwą drogę od scjentyzmu i socjalizmu do personalizmu; jednocześnie odkrył Boga w katolicyzmie, choć od urodzenia był protestantem. Oba nurty życiowe tego filozofa sprawiły, iż zaczął się żywo interesować relacjami między osobą a wspólnotą, zwłaszcza wspólnotą polityczną.

Jak zauważa w jednej ze swojej książek, ,życie społeczne jest zatem naturalnym życiem człowieka, odpowiadającym najgłębszym potrzebom tego gatunku"26. Kwestia społeczna była dla niego bardzo istotna. Potwierdza to nie tylko jego myśl filozoficzna spisana $\mathrm{w}$ wielu publikacjach, ale przede wszystkim czyny. Już w trakcie II wojny światowej, przebywając najpierw w USA, a później będąc ambasado-

${ }^{20}$ Mowa jest tutaj o stadium estetycznym, etycznym i religijnym. Więcej w: M. Mazurkiewicz, Jednostka a absolut w filozofii Sørena Kierkegaarda, „Studia Redemptorystowskie” 2005, nr 2, s. 97-119.

${ }^{21}$ K. Sacharczuk, Mounierowskie..., dz. cyt., s. 107.

22 K. Sacharczuk, Mounierowskie..., dz. cyt., s. 108.

${ }^{23}$ Koncepcja odpowiedzialności jest szeroko komentowana, zwłaszcza w filozofii XX w. na styku personalizmu, filozofii dialogu i filozofii spotkania. Więcej w: J. Filek, Filozofia odpowiedzialności XX wieku, Kraków 2003.

24 K. Sacharczuk, Mounierowskie..., dz. cyt., s. 107.

25 S. Kowalczyk, Personalizm społeczny Emmanuela Mouniera, „Roczniki Nauk Społecznych" 1990, nr 1, s. 145-146.

26 J. Maritain, Trzej reformatorzy: Luter, Kartezjusz, Rousseau, przeł. K. Michalski, Warszawa-Ząbki 2005, s. 172. 
rem Francji przy Stolicy Apostolskiej, apelował do nowo utworzonej Organizacji Narodów Zjednoczonych, aby bronić podstawowych praw człowieka ${ }^{27}$. W jego refleksji znajdujemy wiele ciekawych rozróżnień, podziałów oraz definicji, które do dzisiaj stanowią podstawę dyskusji, również w świecie filozofów społecznych oraz politycznych. Jednym z tych rozróżnień jest kwestia dotycząca społeczności i społeczeństwa. Jaka jest zatem różnica w tych dwóch, podobnie brzmiących do siebie definicjach? Według Maritaina różnica tkwi w „sile napędowej” tych dwóch grup. Społeczność to sfera, która powstała na bazie tradycji sięgających do rozumu, który wprowadza wartości. Społeczeństwo zaś to sfera działań osobowych tzn. podjętych dobrowolnie przez konkretne osoby w imię swojej własnej wolności ${ }^{28}$. W tym miejscu należałoby zadać pytanie, do jakiej grupy przyporządkować „ciało polityczne”? Odpowiedź udzielona przez autora Człowiek i państwo jest jednoznaczna. We wspomnianej książce czytamy, że „w społeczeństwie presja społeczna wynika z prawa i racjonalnych reguł, czyli z idei wspólnego celu; odwołuje się do osobistego sumienia i wolności, które muszą przestrzegać prawa z własnej woli” ${ }^{29}$. „Ciało polityczne” jest społecznością, ponieważ dąży do realizacji wspólnych celów. Najlepiej jednak, aby tym celem było dobro wspólne wszystkich interesariuszy. Taką możliwość Maritain widzi w demokracji, którą uznaje za formę życia politycznego chroniącą wolność i dbającą o dobro wspólne. Należy jednak podkreślić, iż w jego ujęciu istnieje wyraźne rozróżnienie demokracji: demokracji liberalnej (która swoimi korzeniami sięga do tradycji angielsko-francuskiej XVI-XVII w.) oraz demokracji opartej na wartościach chrześcijańskich. Demokrację tę nazywa „personalistyczną” ${ }^{30}$. Należy zatem wskazać, jakie są cechy tejże demokracji „,personalistycznej”. Pierwsza zasada określona przez Maritaina to pluralizm. Zasada ta zakłada, że jeśli w demokracji będą stosowane podstawowe prawa i obowiązki, których korzenie będą sięgać tradycji chrześcijańskich to należy również do głosu dopuścić wszystkich tych, którzy mają odmienne poglądy. Warunkiem takiego dopuszczenia jest działanie w granicach określonych przez wyrażoną koncepcję dobra wspólnego oraz ustanowionego prawa $^{31}$. Druga kwestia dotyczy wolności w myśli i działaniu. Autor książki Człowiek i państwo ukazuje dwie strony rozumienia wolności w życiu społeczno-politycznym. $Z$ jednej strony zastrzega, że nie jest prawdą, że wolność słowa polega na wypowiadaniu wszystkiego, co zostanie „wymyślone” przez człowieka ${ }^{32}$. Tutaj można zauważyć konkretną różnicę między demokracją liberalną, a personalistyczną postulowaną przez Maritaina. W demokracji liberalnej czy nawet libertariańskiej

27 W. Kołodziejczak, Jacques Maritain - u źródeł współczesnych koncepcji praw człowieka, „Studenckie Zeszyty Naukowe” 2015, nr 26, s. 18.

28 J. Turek, Zasada dobra wspólnego a demokracja. Próba analizy stanowiska J. Maritaina, „Annales. Etyka w życiu gospodarczym” 2008, nr 1, s. 98.

29 J. Maritain, Człowiek i państwo, przeł. A. Grobler, Kraków 1993, s. 10.

30 J. Maritain, Człowiek..., dz. cyt., s. 117.

31 J. Maritain, Człowiek..., dz. cyt., s. 121-122.

32 J. Maritain, Człowiek..., dz. cyt., s. 124. 
widzialne są skrajne głosy. Można przytoczyć w tym miejscu wspominanego już I. Berlina, który opisuje wolność w sposób „pozytywny” (wolność, której granice wyznaczają m.in. instytucje) i „negatywny” (wolność, której granice wyznacza człowiek sam dla siebie), zaznaczając, że druga koncepcja wolności jest zdecydowanie lepsza. Podobny pogląd przytacza amerykański neopragmatysta R. Rorty, który widział w „wolności negatywnej” możliwość buntu wobec wszystkich, którzy narzucają jakiekolwiek schematy, granice, prawa zmuszające do określonych działań ${ }^{33}$. Maritain w opozycji wskazuje na trzy elementy, w których wolność może zostać ograniczona: granica wolności słowa wynika z dobra wspólnego; państwo może narzucać ograniczenia wolności słowa w szczególnych okolicznościach; ograniczenie wolności słowa powinno wynikać z obowiązującego prawa i działania określonych struktur $^{34}$. Druga zaś strona wolności bezpośrednio wynika z opisanych wyżej właściwości stosowania granicy wolności. Ten francuski personalista wyraża stanowisko, że państwo demokratyczne nie powinno stosować narzędzi negatywnych w ograniczaniu wolności słowa, gdyż zawsze obraca się to przeciwko władzy. Pisze Maritain, że „nie tylko cenzura i metody polityczne, ale jakiekolwiek bezpośrednie ograniczanie wolności słowa [...] są najgorszym sposobem zapewnienia ciału politycznemu prawa do obrony wolności, karty moralności publicznej" ${ }^{35}$. Stąd domaga się, aby państwo działało i interweniowało w sytuacjach, w których zagrożone jest dobro wspólne. W innych sytuacjach działanie w granicach prawa powinno pozostać nienaruszone. Trzecia zasada, po pluralizmie i wolności, dotyczy edukacji. Chcąc mieć społeczeństwo aktywne i świadome, autor Człowiek i państwo postuluje, aby rodzina we współpracy z państwem stała na straży nauczania podstawowych wartości $^{36}$. Celem takiego działania jest jedność na rzecz karty demokratycznej ${ }^{37}$.

\section{O demokracji zbudowanej na wartościach obiektywnych - Józef Tischner}

W tekstach ks. Józefa Tischnera (1931-2000), zaliczanego do grona polskich personalistów, również znajdujemy refleksję nad kwestią państwa demokratycznego. Zainteresowanie się tym tematem przez krakowskiego filozofa, wynika z jednej strony z negacji totalitaryzmów oraz systemów filozoficznych Hegla i Marksa, na gruncie których powstał socjalizm czy komunizm. Z drugiej strony warto zwrócić uwagę, iż demokracji rozumianej jako współczesny system polityczny, Polska zaczęła się „uczyć” po roku 1989. Są to czasy, w których żył i tworzył Józef Tischner. Na wstępie należy uwzględnić elementy, które mogą pomóc w uporządkowaniu treści w tym zakresie. Poglądy te w dużej mierze mają ugruntowanie filozoficzne, ale są też wynikiem osobistych przemyśleń Józefa Tischnera. Należy zatem potraktować

\footnotetext{
${ }^{33}$ M. Kilanowski, Ku wolności jako odpowiedzialności, Toruń 2013, s. 241.

34 J. Maritain, Człowiek..., dz. cyt., s. 124-125.

35 J. Maritain, Człowiek..., dz. cyt., s. 125.

36 J. Maritain, Człowiek..., dz. cyt., s. 128.

37 J. Maritain, Człowiek..., dz. cyt., s. 129.
} 
tę część artykułu jako ogólne przedstawienie myśli tego autora, zdając sobie jednocześnie sprawę z sytuacji społeczno-politycznej jaka panowała w Polsce po $1989 \mathrm{r}$. Należy także dodać, iż wizja państwa i demokracji u Józefa Tischnera wynika także z jego przynależności do Kościoła Katolickiego oraz myśli społecznej Kościoła, która została wyrażona we współpracy z katolicką nauką społeczną.

Pisząc o państwie w książce Nieszczęsny dar wolności autor zaznacza, iż „państwo [...] nie jest rzeczywistością poza dobrem i złem. [...] Państwo stoi na straży dobra wspólnego. Wartością podstawową w obszarze dobra wspólnego - jak uczy katolicka nauka społeczna - jest pokój społeczny. Zachowanie pokoju społecznego, a więc w pewnym sensie prawa do życia każdego obywatela, jest przedmiotem szczególnej troski państwa”"38. W tej „definicji” państwa należy zwrócić uwagę na dwa aspekty. Pierwszym z nich jest fakt, że państwo jako organizm instytucyjny nie jest wyłączone z obszaru etycznego. Można wręcz powiedzieć o konkretnym etosie państwa. Trudno zatem - w ocenie Józefa Tischnera - zbudować państwo bez wartości. Odwołuje się on tutaj także do katolickiej nauki społecznej. To drugi aspekt związany z rozumieniem państwa, a także i demokracji przez krakowskiego filozofa XX w. Państwo i demokracja powinny być zbudowane na wartościach, również tych, które są proponowane przez chrześcijaństwo w szerszym znaczeniu, zaś w węższym przez Kościół Katolicki. Zostało to wyrażone przez ks. Józefa Tischnera w książce Idąc przez puste Błonia, w których autor odwołuje się do tekstów papieża Jana Pawła II. W tej samej pozycji, autor wskazuje, iż państwo ,prawdziwe” to państwo zbudowane na zasadach prawa i etyki. Państwo „prawdziwe” cechuje się właściwym rozumieniem człowieka. Rozumienie to jest oparte na ideale wolności, który pozwala na właściwe działanie ${ }^{39}$. Wolność zaś należy tutaj rozumieć jako możliwość wyboru. Jest to wybór wartości. Tischner zapisze to w następujący sposób: „dzięki wolności człowiek czyni siebie prawdomównym lub kłamcą, sprawiedliwym lub niesprawiedliwym, przebaczającym lub mściwym. Nie można być sobą, jeśli się nie jest wolnym"40. Wolność także według tej koncepcji łączy się z dobrem. Związek ten oznacza, że wolność jest czymś więcej niż zwykłą możnością wyboru. Nie dokonuje się tego wyboru dla samego faktu działania, ale dlatego, żeby urzeczywistnić jakieś dobro ${ }^{41}$. Wcześniej zostało wspomniane, że wolność jest właściwym elementem filozofii dramatu. Pojęcie to na trwale wpisuje się w filozofię Józefa Tischnera i jak widać należy go łączyć z wartością, między wyborem dobra i zła.

Demokrację Tischner rozumiał jako przejście-proces od pojawienia się idei do jej urzeczywistnienia w ruchu społecznym ${ }^{42}$. O tym, czy państwo jest demokratyczne decyduje idea, która umożliwia wspólnotowe skupienie serc ludzkich. Idea demokratyczna - w ocenie krakowskiego filozofa - powinna skupiać wokół siebie dwie cechy:

38 J. Tischner, Nieszczęsny dar wolności, Kraków 1993, s. 139-140.

39 J. Tischner, Idac przez puste Błonia, Kraków 2014, s. 160.

40 J. Tischner, Idac ..., dz. cyt., s. 159.

${ }^{41}$ J. Gowin, Religia i ludzkie biedy. Ks. Tischnera spory o Kościót, Kraków 2003, s. 78.

42 J. Tischner, Etyka solidarności, Kraków 2000, s. 56. 
rozumność i wolnośćt3. Idea jest rozumna, gdy stanowi podstawę ładu społecznego, tzn. w sposób właściwy zostają określone cele oraz zadania do realizacji i w ramach tych celów we właściwy sposób następuje podział zadań. Rozumność to harmonia między funkcjami społecznymi ${ }^{44}$. Drugi aspekt jest związany z horyzontem wolności. Idea, która ma mieć charakter demokratyczny powinna zezwalać na spontaniczne działanie człowieka jako jednostki. W tym wolnościowym akcie człowieka można dostrzec jego bogactwo i zasoby, które mogą pomóc w stworzeniu demokratycznego państwa ${ }^{45}$. Wolność jednak nie oznacza, iż człowiekowi można czynić wszystko. Tischner świadomy pewnej sprzeczności między rozumnością, która pozwala większość spraw przewidzieć, a wolnością, która może zaburzyć harmonię, wprowadza pojęcie godności. Godność jest spoiwem, które w sposób właściwy wyrównuje tę dysproporcję $^{46}$. W końcu państwo demokratyczne to „organizacja”, która w życiu społecznym potrafi rozwiązywać napięcia i konflikty na drodze dialogu, nie zaś na drodze siły ${ }^{47}$.

\section{Podsumowanie}

We wszystkich trzech przedstawionych „projektach” demokracja jest zbudowana na wartościach. Wartości te mają jednak inne korzenie, niż zaproponowana i umacniana koncepcja demokracji liberalnej. Wolność w ujęciu personalizmu nie polega na dowolnym działaniu. Jest ona wynikiem refleksji, także na gruncie etyki, której skutkiem jest podjęcie decyzji. Człowiek podejmujący działanie jest świadom odpowiedzialności za siebie oraz za drugiego człowieka. Demokracja personalistyczna jest systemem, w którym każdy podlega określonym prawom i obowiązkom, zaś władza ma na celu ochronę podstawowych wartości oraz dobra wspólnego. Opisane powyżej propozycje mogą być inspiracją dla wszystkich, którzy współcześnie podejmują dyskusje na temat kształtu państwa demokratycznego. Oczywiście należy podkreślić, iż poruszane tutaj kwestie nie wyczerpują w całości zagadnienia. Personalizm tworząc także własne spojrzenie na kwestie społeczno-polityczne włączył się do żywej dyskusji trwającej na gruncie socjologii, politologii czy filozofii społecznej oraz filozofii politycznej. Nie jest zatem jedynym głosem, a na pewno nie jest głosem dominującym. Wszelka wymiana argumentów pomiędzy przedstawicielami takich nurtów jak: liberalizm, komunitaryzm czy personalizm może zaowocować ciekawymi propozycjami rozwiązania problemu, który określić można pytaniem: jak rozumieć demokracje? Tak jak zostało wskazane, pojęcie to przechodziło przez różnego rodzaju reformy. Wydaje się jednak, że najważniejszym jest to, aby pamiętać że wszelki ustrój polityczny powinien jak najlepiej służyć rozwojowi konkretnego obywatela, ale także narodowi jako całości wspólnoty politycznej.

43 J. Tischner, Etyka..., dz. cyt., s 56.

44 J. Tischner, Etyka..., dz. cyt., s. 57.

45 J. Tischner, Etyka..., dz. cyt., s. 57.

46 J. Tischner, Etyka..., dz. cyt., s. 57.

47 J. Tischner, Idac ..., dz. cyt., s. 164. 


\section{BIBLIOGRAFIA}

\section{Opracowania:}

Bartnik Cz., Personalizm, Lublin 2008.

Filek J., Filozofia odpowiedzialności XX wieku, Kraków 2003.

Gowin J., Religia i ludzkie biedy. Ks. Tischnera spory o Kościót, Kraków 2003.

Guzowski K., Kosche M., Personalizm jako próba jednoczenia „zwaśnionych” antropologii, „Horyznoty Polityki” 2016, nr 19, s. 57-75.

Hayek F., Indywidualizm i porzadek ekonomiczny, przeł. G. Łuczkiewicz, Kraków 1998.

Kilanowski M., Ku wolności jako odpowiedzialności, Torun 2013.

Kołodziejczak W., Jacques Maritain - u źródet wspótczesnych koncepcji praw człowieka, „Studenckie Zeszyty Naukowe” 2015, nr 26, s. 17-25.

Kowalczyk S., Człowiek a społeczność. Zarys filozofii społecznej, Lublin 2005.

Kowalczyk S., Personalizm społeczny Emmanuela Mouniera, „Roczniki Nauk Społecznych" 1990, nr 1, s. 129-149.

Malmon M., Arystotelesa poszukiwania idealnego ustroju państwowego, „Kultura i Wartości” 2016, nr 2, s. 9-19.

Maritain J., Człowiek i państwo, przeł. A. Grobler, Kraków 1993.

Maritain J., Trzej reformatorzy: Luter, Kartezjusz, Rousseau, przeł. K. Michalski, Warszawa-Ząbki 2005.

Mazurkiewicz M., Jednostka a absolut w filozofii Sørena Kierkegaarda, „Studia Redemptorystowskie" 2005, $\mathrm{nr}$ 2, s. 97-119.

Mounier E., Co to jest personalizm, przeł. E. Krasnowolska, Warszawa 1964.

Raburski T., Niccolò Machiavelli: klasyczny realizm i republikanizm, „Filozofia Publiczna i Edukacja Demokratyczna” 2011, nr 1, s. 111-119.

Rorty R., Obiektywność, relatywizm, prawda, przeł. J. Margański, Warszawa 1999.

Sacharczuk K., Mounierowskie rozumienie wolności, zaangażowania i komunikacji dla praksis życia osobowego człowieka, „Bielańskie Studia Teologiczne” 2016, nr 2, s. 103-116.

Słupik T., Narodziny demokracji w Grecji klasycznej w czasach reform Klejstenesa i Peryklesa, „Studia Politicae Universitatis Silesiensis” 2017, nr 19, s. 35-68.

Swift A., Wprowadzenie do filozofii politycznej, przeł. A. Krzynówek, Kraków 2010.

Szewczyk W., Kim jest człowiek. Zarys antropologii filozoficznej, Tarnów 2009.

Ślipko T., Zarys etyki szczegółowej, t. 2, Kraków 2010.

Tischner J., Etyka solidarności, Kraków 2000.

Tischner J., Idac przez puste Błonia, Kraków 2014.

Tischner J., Nieszczęsny dar wolności, Kraków 1993. 
Turek J., Zasada dobra wspólnego a demokracja. Próba analizy stanowiska J. Maritaina, „Annales. Etyka w życiu gospodarczym” 2008, nr 1, s. 87-94.

Zdebski H., Historia myśli politycznej i prawnej, Warszawa 2013.

Zwoliński A., Wprowadzenie do rozważań o narodzie, Kraków 2005.

\section{Streszczenie}

Obchodząc 100-lecie odzyskania przez Polskę niepodległości przedstawiciele różnych dyscyplin humanistycznych podejmują refleksję na temat relacji łączących państwo. Artykuł ten jest głosem dotyczącym propozycji rozumienia demokracji przez przedstawicieli personalizmu. Wśród różnych koncepcji opisujących „,rządy ludu" pojawia się projekt stawiający w celu osobę, która jest podmiotem działania, zaś celem tego działania jest dobro wspólne. Artykuł ten przedstawia propozycję trzech filozofów: E. Mouniera, J. Maritain oraz J. Tischnera.

Słowa klucze: personalizm, demokracja, filozofia polityczna, osoba, wolność

\section{Examples from Selected Representatives of the Twentieth Century Personalism on Democracy and Social Issues \\ Summary}

Celebrating the 100th anniversary of Poland's independence, representatives of various humanistic disciplines reflect on relations between the state. This article is about the proposal to understand democracy by representatives of personalism. Among the various concepts describing the ,rule of the people" there is a one aimed at the person who is the subject of action, and the goal of this action is the common good. This article presents the proposal of three philosophers: E. Mounier, J. Maritain and J. Tischner.

Key words: personalism, democracy, political philosophy, person, freedom 